\title{
VARIATION IN WILD POPULATIONS OF PAPAVER DUBIUM \\ VII. GERMINATION TIME
}

\author{
A. E. ARTHUR*, J. S. GALE and M. J. LAWRENCE \\ Department of Genetics, University of Birmingham, Birmingham B15 2TT
}

Received 26.iv.72

\section{SUMMARY}

Previous workers have noted that seéds of Papaver dubium may germinate either in autumn or in spring and that autumn germinators do not survive a severe winter. If the winter is mild, the proportion of autumn germinators surviving and ultimately reaching maturity can rise as high as 84 per cent. Survivors greatly exceed spring germinators in mean seed output per plant. Even when allowance is made for the lower survival of autumn germinators as compared with spring, the autumn types are still at an immense advantage over the spring types, given a mild winter. Hence autumn germinators are at an advantage over spring germinators in some years but not in others. Autumn germinators which survive are very much taller and flower earlier than their spring counterparts, presumably reflecting their greater competitive ability. The time of germination (autumn $v$. spring) showed a very low, possibly zero, heritability in the population studied. It is concluded that selection has favoured those plants capable of producing a mixture of the two types of seed.

\section{INTRODUGTION}

IT has been shown (Lawrence, 1965, 1972; Gale and Arthur, 1972; Gale and Eaves, 1972) that at least 14 characters show genetic variation within at least some natural populations of Papaver dubium. However, apart from capsule number, which is known to be an important component of fitness, the significance of these characters in the life of the plant has been established only tentatively by indirect arguments in the case of some characters and is altogether uncertain for others (Arthur, Rana, Gale, Humphreys and Lawrence, 1972). For this reason we have chosen for detailed investigation a character, germination time, which, as we shall show, has a very striking effect on fitness. It has indeed long been recognised (Harper, 1965) that early germination would imply that the resulting plants would have a large competitive advantage over those plants appearing later, provided of course that the early germinators were able to withstand the rigours of the climate at their time of germination. Now poppies, under natural conditions, exhibit a very wide distribution of germination times. In particular, a proportion of seed germinate in the autumn. We shall concentrate here on the distinction between autumn and spring germination and, for brevity, refer to autumn and spring germinators as $\mathrm{A}$ and $\mathrm{S}$ respectively. It will also be convenient to use the term "germination time" to refer to the season of the year in which germination occurs, although there is also considerable variation in times of germination within either season.

Now, if the winter is severe, the autumn germinators nearly always die during the winter period (McNaughton, 1959-quoted in McNaughton

* Present address: John Innes Institute, Colney Lane, Norwich, NOR 70F. 
and Harper, 1964). However, as we shall show, in a mild winter a substantial proportion overwinter successfully and contribute to the adult population in the following summer. Thus, given a mild winter, we might expect that the autumn germinators would have a considerable advantage over their spring counterparts. We shall describe experiments designed to investigate three problems, namely (1) the relative fitnesses of A as compared with S plants, (2) possible associations between time of germination and two other characters, flowering time and adult height, and finally (3) whether differences in germination time are under genetical control.

\section{Materials AND methods}

It is, of course, essential to grow the plants under as natural conditions as possible. As it proved impracticable to observe a natural population, we have tried to simulate conditions in nature. In October 1964, two artificial populations were set up. Two previously grassed-over plots, hereinafter referred to as the north and south plots, each measuring 30 feet by 4 feet, were cleared. The plots were situated a few yards apart. About 100,000 seeds from about 100 plants growing on the University campus at a distance of 300-400 yards from the plots were scattered on each plot. The north plot was allowed to seed itself in 1965 and 1966. In 1965, seed was prevented from falling on the south plot by removing all, or almost all, capsules before they had ripened. The number of seedlings appearing on the south plot in 1966 was considerably lower than on the north plot in 1966 or on the south plot in 1965. Since a large reservoir of seed must still have been present on the south plot in 1966, this tentatively suggests that the bulk of the germination in a given year arises from seed produced the previous year. In 1966, the south plot was allowed to seed itself. No further seed was added at any time, no fertiliser was given and weeding was kept to an absolute minimum. Unfortunately, the south plot became completely overgrown by couch grass and Yorkshire fog by the end of the summer of 1967 and observations on that plot had to be discontinued after that time.

Observations relevant to the present study began at the start of autumn germination in late October 1966. Each plot was divided by string into 120 one-foot squares to facilitate recording of positions of plants. In early November, a map was drawn up of the plots, recording the position of every recently germinated plant. It was intended to observe the plots at regular intervals and record on the map any deaths of seedlings noted earlier and any new seedlings appearing. It proved impossible to do this in rain, when there was a snow cover, a hard frost making it difficult to distinguish poppy seedlings from those of other species, or when the light was bad. However, since germination in the second half of December and most of January proved to be zero, no serious practical difficulties arose. This pause in germination was used to define the difference between $\mathrm{A}$ and $\mathrm{S}$, any plants appearing after the pause being classified as $\mathrm{S}$ plants. These first appeared in late January. At this stage A seedlings, most of which have at least 3-4 true leaves, are easily distinguished from the $\mathrm{S}$, which are still at the cotyledon stage. Later, the distinction becomes more difficult. Hence, to facilitate accurate recording on the map, small rings were placed round the A plants early in March. These rings tend to be buried in the soil by the end of the season and we have found it best to attach the usual small tags to plants 
when these are large enough to carry tags without risk of damage, germination time being indicated by the colour of the tag.

In 1967 we found it difficult to record deaths of S plants, since they tended to appear in clusters. Certainly, this mortality was very low. In that we shall have to take the survival of $S$ plants as 100 per cent. in 1967 , we shall slightly exaggerate their fitness, but, as we shall see, this causes no difficulties. No such problems were experienced in recording deaths of A plants.

Flowering began on 10th June. All plants were left to open pollinate. As far as possible, the flowering times of all plants were recorded. A few plants were missed and some others could not be scored owing to bird damage. On 17th June, $20 \mathrm{~A}$ and $20 \mathrm{~S}$ plants were chosen at random and their heights measured. A little later $10 \mathrm{~A}$ and $10 \mathrm{~S}$ plants were chosen at random, so that ultimately their seed output could be counted. In order to prevent loss of seed, capsules were sealed with "parafilm" a few days before dehiscence. Finally, at the end of the summer, the capsule number of all remaining plants was determined. Fortunately, in cases where flowers had been damaged by birds, the flower stalks still remained; in such cases, a flower stalk without a capsule was scored as a capsule, since in our experience every undamaged flower is pollinated and gives rise to seed, provided of course that the plant survives until seed is ripe.

While the number of $\mathrm{A}$ and $\mathrm{S}$ plants at the various stages and also plant height were recorded on both plots, flowering time, capsule number and seed counts were recorded on the north plot only.

The procedure in 1967-8 was very similar to that just given. Plants were again allowed to open pollinate, except for a few cases described below. To eliminate bird damage, the plot was covered by a net. Flowering began on 12th June. Flowering time was recorded on a random sample (91 A, $106 \mathrm{~S}$ ) of plants instead of all plants, as in the previous year. Height was measured on these same plants at the end of May. By the end of the season, the sample had been reduced by natural mortality to $90 \mathrm{~A}$ and $94 \mathrm{~S}$ (openpollinated) plants and capsule number was determined on these. Seed counts were also made on these, apart from four A plants which were unaccountably lost. Thus the allocation of time to the various measurements was, hopefully, put on a more rational basis in 1967-8, as a result of experience gained in the previous year. No difficulty was experienced in scoring the survival of $\mathrm{S}$ plants.

In 1968-9, only autumn germination and survival of A plants, together with the contribution of these $\mathrm{A}$ plants to the adult population, were recorded. This was done in the hope that the winter would be more severe than in previous years, giving an opportunity to confirm that McNaughton's results applied to our population.

\section{Differences between AUtumn AND SPRing Germinators}

We first consider survival rates, up to the flowering period, as given in table 1 .

It is clear that, in the relatively mild winters of $1966-7$ and $1967-8$, the A plants coped well with winter conditions. Rather surprisingly, many of those which died during the rather less favourable winter of 1966-7 did so during a mild period in late February, suggesting that damage to the plant, presumably by frost, takes effect rather slowly. It is interesting to note the 
substantially greater damage on the south plot; on inspection during a cold period this plot appeared more severely affected by frost than did the north plot. Some of the losses, however, occurred on the south plot well after February and represent the effects of encroaching grass. Although we have no accurate counts, there is no doubt that the $S$ plants also suffered from this and survived less well than on the north plot. Nevertheless, there is clearly a real difference between plots in relative survival rate of $A$ and $S$. The last column of table 1 gives the proportion of A plants among all plants present

TABLE 1

Numbers and survival of autumn germinating $(A)$ and spring germinating $(S)$ plants

$\begin{array}{cccccc}\text { Experiment } & \begin{array}{c}\text { Number } \\ \text { of A } \\ \text { arising }\end{array} & \begin{array}{c}\text { Survival } \\ \text { of A } \\ (\%)\end{array} & \begin{array}{c}\text { Number } \\ \text { of S } \\ \text { arising }\end{array} & \begin{array}{c}\text { Survival of S } \\ (\%) \\ \text { probably } \\ \text { high }\end{array} & \begin{array}{c}\text { Percentage A } \\ \text { at maturity }\end{array} \\ \text { 1966-7 North plot } & 758 & 56.1 & 1553 & 21.5 \\ \text { South plot } & 86 & 25.6 & 170 & \begin{array}{c}\text { probably } \\ \text { fairly high }\end{array} & 11.5 \\ \text { 1967-8 North plot } & 751 & 83.8 & 3018 & 97.7 & 17.6 \\ \text { 1968-9 North plot } & 2113 & 3.9 & - & - & 4.2\end{array}$

at maturity (beginning of the flowering period). Clearly A plants on the south plot did less well, in comparison with $\mathrm{S}$, than on the north plot.

In striking contrast are the results from 1968-9, where a spell of severe frost eliminated almost all the A plants, in agreement with the results of McNaughton (McNaughton and Harper, 1964).

We turn now to the capsule and seed counts, given in tables 2 and 3 respectively.

TABLE 2

Capsule numbers

Experiment

1966-7 North plot 1967-8 North plot

Experiment

1966-7 North plot 1967-8 North plot

$\begin{array}{cc}\text { Number } & \text { Mean } \\ \text { of A } & \text { num } \\ \text { scored } & \text { per } \\ 396 & \\ 90 & \\ & \\ \text { Number of A } \\ \text { scored } \\ 10\end{array}$

86

$\begin{array}{cc}\text { Mean capsule } & \text { Number } \\ \text { number } & \text { of S } \\ \text { per plant } & \text { scored } \\ 1.89 & 1014 \\ 1.40 & 94\end{array}$

TABLE 3

Seed numbers

Mean number
of seeds
per plant

$1205 \cdot 9$

$284 \cdot 7$

$\begin{array}{ccc}\begin{array}{c}\text { Mean capsule } \\ \text { number }\end{array} & & \\ \text { per plant } & t & P \\ 1 \cdot 10 & 18.68 & <0.1 \% \\ 0.85 & 10.85 & <0.1 \%\end{array}$

It is apparent that the mean capsule number per plant at the end of the season is significantly and strikingly higher in the A plants than in the $\mathrm{S}$ plants, in the ratio $1.72: 1$ and $1.65: 1$ in the two years respectively. However, even more striking are the mean number of seeds per plant, A plants producing, on average, about 69 times as much seed as $\mathrm{S}$ in one year and 21 times in the other. Now the survival rate for A in 1966-7 was 56.1 per cent. Even if we take the survival rate for $S$ to be 100 per cent., A plants will be $0.561 \times 69=39$ times fitter than $S$, on the north plot. If 
our seed counts are applicable to the south plot, the corresponding figure is 18 times. In 1967-8, where we can get a more exact result since the survival rate of $\mathrm{S}$ plants is known, the value is 18 times. Clearly, if the winter is mild, an average A plant is at an enormous advantage over an average $S$ plant and in these circumstances most of the seed falling on the soil will arise from A plants in spite of the fact that, initially, more S appear than A.

The reason for this difference in fitness between $\mathrm{A}$ and $\mathrm{S}$ plants becomes clearer on inspection of the data for height, given in table 4.

TABLE 4

Plant adult height $(\mathrm{mm}$.

$\begin{array}{rcccccc}\text { Experiment } & \begin{array}{c}\text { Number of A } \\ \text { scored }\end{array} & \begin{array}{c}\text { Mean } \\ \text { height }\end{array} & \begin{array}{c}\text { Number of S } \\ \text { scored }\end{array} & \begin{array}{c}\text { Mean } \\ \text { height }\end{array} & \boldsymbol{t} & \text { P } \\ \text { 1966.7 North plot } & 20 & 165.50 & 20 & 18 \cdot 75 & 9.01 & <0.1 \% \\ \text { South plot } & 14 & 116.79 & 14 & 33.93 & 3.03 & 1 \% \\ 1967-8 \text { North plot } & 91 & 111.21 & 106 & 21.70 & 11 \cdot 13 & <0.1 \%\end{array}$

Clearly, the A plants are very much taller, on average, than the S. It seems almost certain, then, that the advantage of A plants lies in their superior competitive ability. In that they are in the true leaf stage at a time when the $\mathrm{S}$ are still in the cotyledon stage, the $\mathrm{A}$ are presumably able to develop more rapidly than the $\mathrm{S}$ and obtain a disproportionate share of light and nutrients. The result is a tall plant, which has obtained sufficient of the limiting resources necessary for growth and is thus able to produce a large amount of seed. We should perhaps emphasise that this seed seems to be of normal viability, although we have no exact measurements of this. The less well supplied S plants concentrate, as is usually the case when plants have inadequate resources (Harper, 1960; Harper and Gajic, 1961), on producing a small number of viable seed rather than a large amount of seed of poor viability.

Finally, we turn to the data on flowering time, as given in table 5 . In view of the bird damage in 1967, results for that year are rather unreliable;

TABle 5

Flowering time in days (day $1=1$ st 7 ume)

$\begin{array}{ccccc}\text { Experiment } & \begin{array}{c}\text { Number of A } \\ \text { scored }\end{array} & \begin{array}{c}\text { Median } \\ \text { flowering time }\end{array} & \begin{array}{c}\text { Number of S } \\ \text { scored }\end{array} & \begin{array}{c}\text { Median } \\ \text { flowering time }\end{array} \\ \text { 1966-7 North plot } & 310 & 18 & 979 & 23 \\ \text { 1967-8 North plot } & 91 & 17 & 106 & 24\end{array}$

the plants most heavily attacked being the largest of the A plants, which might perhaps have been the first to flower. For this reason, we have given median flowering times, since the median would be less likely than the mean to be badly biased under these circumstances. It is apparent that the median flowering time for $\mathrm{A}$ is earlier than for $\mathrm{S}$, being 5 days earlier in 1967 and 7 days in 1968. In fact, the means also differ by 5 and 7 days respectively. These differences are highly significant $(t=14.30, \mathrm{P}<0.1$ per cent. and $t=6 \cdot 70, \mathrm{P}<0 \cdot 1$ per cent.).

This difference in flowering time indicates a serious problem if one wishes to determine the fitness of different phenotypes for a given character. For example, in 1965, plants growing on the north and south plots exhibited a clear relationship between flowering time and capsule number, the latter 
falling off quite strikingly with flowering time, so that early flowering plants have about $3 \frac{1}{2}$ times as many capsules as the late. At first sight this looks like a straightforward case of directional selection for genes controlling flowering time. However, from the results on germination time just given, it seems very likely that the early flowering plants in 1965 were mainly A plants and the late flowerers mainly $\mathrm{S}$ plants. Thus both early flowering and greater number of capsules would simply be a secondary consequence of the manner of growth of A plants and similarly for the late flowering, low capsule number S plants. An attempt was made in 1968 to see if there was any relationship between flowering time and seed count if we confine ourselves either to A plants only or to S plants only. The results were inconclusive; in any case, any difference found could be merely a reflexion of differences in germination time within a season. We conclude that the type of experiment just described tells us very little about the relationship between fitness and genes controlling flowering time or any of the other characters known to show genetic variation in this population (Gale and Eaves, 1972), apart perhaps for capsule number. A more elaborate experiment is required.

Clearly, before any hypothesis can be formulated about the role of germination time in the population genetics of the species, it is essential to establish whether germination time does show heritable variation in this population and we shall now describe an attempt to investigate this.

\section{Is GERMiNATION TIME A HERITABLE TRAIT?}

In 1968, 20 randomly chosen A plants and 20 randomly chosen $S$ plants growing on the plot, were selfed, in order to determine whether seed derived from A plants would show a higher proportion of autumn germination than seed from S plants. However, the seed output of the $\mathrm{S}$ plants was too low for an immediate test of this kind to be made. Accordingly, it was decided to raise a single plant from each of the 40 sets of seed, on the experimental field, in order to proliferate seed. These plants were raised in 1969 and selfed, thus giving rise to 40 batches of seed, 20 derived ultimately from the original 20 A plants and 20 from the original S plants. An attempt to determine germination time on these 40 batches failed for technical reasons (see below). Hence it was necessary, in order to repeat the germination test in 1970 , to raise a single plant from every batch and self these plants. This was done, on the experimental field, in 1970. Thus we had available 40 batches of newly produced seed, 20 deriving from 20 A great-grandparents and the other 20 from $20 \mathrm{~S}$ great-grandparents.

The north plot had by this time been abandoned and proved a suitable site for the germination test. Soil was removed to a depth of several inches and sterilised. A lattice was then constructed with planks, so as to give 50 cells, each 1 foot square and 4 inches deep. The lattice was placed on the plot area and the cells partially filled with the sterilised soil. In order to prevent passage of seed from one cell to another, we found it essential to keep the soil level at $1 \frac{1}{2}$ inches below the top of the lattice. Even then a small amount of contamination occurred. In the original attempt we had used a depth of 1 inch only, in order to reduce any effects of shading. This led to serious contamination of cells by seed from other cells.

In September 1970, about 4000 seeds were taken from each batch. Batches were assigned randomly to cells and this seed scattered over the soil 
in the appropriate cells. Ten cells were left unsown as a check on contamination.

Cells were inspected at intervals, about weekly during periods of high germination and otherwise about fortnightly, weather permitting. Autumn germination ceased about mid-December and spring germination began about the third week in January. On each inspection, the number of seedlings in each cell was recorded; after a seedling had been recorded, its aerial portion was removed with forceps. Results are given in table 6 .

TABLE 6

Time of germination of seeds derived from 20 autumn and 20 spring germinators

Seed from autumn germinators

$\begin{array}{cc}\text { Total } & \begin{array}{c}\text { Percentage } \\ \text { germinating } \\ \text { in autumn }\end{array} \\ 588 & 74 \cdot 8 \\ 615 & 24 \cdot 9 \\ 828 & 42 \cdot 8 \\ 377 & 26 \cdot 5 \\ 456 & 47 \cdot 4 \\ 537 & 42 \cdot 5 \\ 1686 & 74 \cdot 9 \\ 1181 & 42 \cdot 3 \\ 734 & 33 \cdot 2 \\ 1715 & 45 \cdot 8 \\ 856 & 36 \cdot 8 \\ 832 & 78 \cdot 8 \\ 942 & 57 \cdot 3 \\ 1027 & 49 \cdot 1 \\ 771 & 88 \cdot 2 \\ 974 & 56 \cdot 1 \\ 1468 & 74.9 \\ 478 & 50 \cdot 2 \\ 392 & 50 \cdot 0 \\ 1147 & 54 \cdot 0 \\ \text { mean } & 52 \cdot 5\end{array}$

Seed from spring germinators

\begin{tabular}{|c|c|}
\hline $\begin{array}{c}\text { Total } \\
\text { germination }\end{array}$ & $\begin{array}{l}\text { Percentage } \\
\text { germinating } \\
\text { in autumn }\end{array}$ \\
\hline 767 & $34 \cdot 7$ \\
\hline 512 & $63 \cdot 7$ \\
\hline 1026 & 37.5 \\
\hline 1075 & $19 \cdot 9$ \\
\hline 276 & $79 \cdot 0$ \\
\hline 470 & $60 \cdot 9$ \\
\hline 331 & $29 \cdot 6$ \\
\hline 678 & 64.9 \\
\hline 1071 & 43.5 \\
\hline 468 & $48 \cdot 7$ \\
\hline 1080 & 34.9 \\
\hline 1293 & $73 \cdot 2$ \\
\hline 987 & 33.7 \\
\hline 739 & $56 \cdot 2$ \\
\hline 1842 & $58 \cdot 2$ \\
\hline 812 & $70 \cdot 2$ \\
\hline 464 & $86 \cdot 6$ \\
\hline 650 & $81 \cdot 4$ \\
\hline 644 & $41 \cdot 8$ \\
\hline \multirow[t]{2}{*}{1037} & $45 \cdot 2$ \\
\hline & 53.2 \\
\hline
\end{tabular}

It is apparent that within either the $\mathrm{A}$ or the $\mathrm{S}$ group there is considerable variation from plant to plant in the estimated proportion of its seed which germinates in the autumn. Since our estimates are based on total germination, which differs considerably from batch to batch, they will differ in their precision. Nevertheless, it is more meaningful to take a simple average of the percentage of autumn germinators of all batches within a group than to weight by the various precisions. By taking the unweighted mean, we correctly average over the various genotypes represented in the 20 parents in a group; the frequencies of these genotypes being roughly representative of genotypic frequencies in the original population. As is shown in table 6 , the mean percentage of autumn germination proves to be

$$
\begin{array}{ll}
\text { autumn group } & 52.5 \\
\text { spring group } & 53.2
\end{array}
$$

Standard errors for these estimates are then estimated in the usual way, that is, we ignore the differences in precision and simply divide the variance of the observed percentages within groups by 20 to obtain the estimated 
variance of the mean. The variances within $\mathrm{A}$ and within $\mathrm{S}$ groups proved to be homogeneous, giving a combined variance of 337.84 for 38 d.f., so that the estimated standard error of either mean is 4.1 per cent.

Thus even if the very close agreement between the means for the two groups is to some extent coincidental, we can conclude with a high degree of confidence that our estimates cannot be very far from the true values and therefore that the heritability of germination time is almost certainly very low in the population studied.

\section{Discussion}

The result just given is surprising for two reasons. Firstly, it has been possible to select against dormancy in the related species Papaver rhoeas; whereas wild $P$. rhoeas shows dormancy, no such dormancy exists in the Shirley poppy, which is a cultivar of $P$. rhoeas. Indeed, up to a point, we have been able to select against dormancy in $P$. dubium. Suppose, in contrast to the situation described in this paper, we wish deliberately to bring about high germination under laboratory conditions. To do this, we have found it necessary to treat seeds with concentrated sulphuric acid followed by a cold "shock" ( $5^{\circ}$ G. $)$. However, by selection we have obtained lines which will germinate without acid treatment provided they are given the cold "shock", i.e. we have broken some component of dormancy. It should be noted, however, that the seed used in this selection experiment was stored in the laboratory and the results may not apply to seed in the soil. McNaughton and Harper (1964) point out that, in addition to the usual innate dormancy, poppy seeds are apparently readily induced to become dormant by burial in soil. Clearly, dormancy in poppies is a complicated phenomenon and the points we have just noted do not, therefore, cast any serious doubt on our conclusion that the heritability of germination time, under natural conditions, is very low in our population. Other populations, of course, could perhaps give different results.

A second cause for surprise is that a character of such importance to the plant should show little or no heritable variation in contrast to most of the other characters studied in this population, in particular capsule number. It should be noted, however, that these other characters were observed under glasshouse or field conditions, under a relatively uniform environment and the heritability of at least some of these characters might be quite low under natural conditions.

It seems that if we are to explain the very low heritability for germination time, we must invoke classical population genetic notions of "selection of the best adapted genotype". That is, we must suppose that a plant capable of producing both $\mathrm{A}$ and $\mathrm{S}$ seed is at an advantage over those producing seed mainly of one type. A plant producing mainly A would be at a serious disadvantage if the seed it produced had to face a succession of harsh winters. A plant producing mainly $\mathrm{S}$ would be disadvantaged if this seed germinated in a succession of springs, each preceded by a mild winter.

On the other hand, the low germination of seed in any one year, together with the long viability of some of the seed, leads to a reservoir of viable seed in the soil, which serves to prevent the permanent extinction of the population under temporary adverse conditions (Harper, 1965). If, then, we think in terms of the single plant rather than the whole population, we conclude 
that a plant producing seed of one type only could ultimately contribute to a future generation, even if, owing to its unsuitable germination time, it failed to contribute for a number of years. However, while this effect would reduce the relative advantage of plants producing seed of both types, it would not abolish this advantage.

Moreover, we pointed out earlier that when a plot was seeded in 1964 but no seed was allowed to fall on the plot in 1965, very few seedlings appeared in 1966. The tentative conclusion, that two-year-old seed contributes little to the current adult population has since been confirmed in another year. Indeed, the low seedling production from old seed seems to be a genieral phenomenon for weed species on undisturbed soil (Roberts and Dawkins, 1967). We are probably justified in concluding that, on undisturbed soil at least, the bulk of seedlings appearing in any year arise from seed produced the previous year. This, of course, would be relevant only in cases where the population continues for some time and not in cases where a long extinct adult population is resurrected by turning over of the soil. If, however, our idea is correct for some situations, the type of weather in the period soon after the seed has fallen would be the critical factor in these cases.

Acknowledgments.-This work was supported by the Agricultural Research Council and a research Studentship given by the Science Research Council.

\section{REFERENCES}

ARTHUR, A. E., RANA, M. S., GALE, J. S., HUMPHREYs, M. O., AND LAWRENCE, M. J. 1973. Variation in wild populations of Papaver dubium. VI. Dominance relationships for genes controlling metrical characters. Heredity, 30, 177-187.

GALE, J. S., AND ARTHUR, A. E. 1972. Variation in wild populations of Papaver dubium. IV. A survey of variation. Heredity, 28, 91-100.

Gale, J. S., AND Eaves, L. J. 1972. Variation in wild populations of Papaver dubium. V. The application of factor analysis to the study of variation. Heredity, 29, 135-149.

HARPER, J. L. 1960. Factors controlling plant numbers. In The Biology of Weeds (ed. Harper), 119-132. Blackwell Scientific Publications, Oxford.

HARPER, J. L. 1965. The nature and consequence of interference amongst plants. In Genetics Today (ed. Geerts), 465-482. Pergamon Press, Oxford.

HARPER, J. L., AND GAJIC, D. 1961. Experimental studies of the mortality and plasticity of a weed. Weed Res., 1, 91-104.

LAWRENCE, M. J. 1965. Variation in wild populations of Papaver dubium. I. Variation within populations; diallel crosses. Heredity, 20, 183-204.

LAWRENCE, M. J. 1972. Variation in wild populations of Papaver dubium. III. The genetics of stigmatic ray number, height and capsule number. Heredity, 28, 71-90.

MCNAUGHTON, I. H., AND HARPER, J. L. 1964. Papaver L. (Biological Flora of the British Isles, no. 99). F. Ecol., 52, 767-793.

ROBERTS, H. A., AND DAWKINS, P. A. 1967. Effect of cultivation on the numbers of viable weed seeds in soil. Weed Res., 7, 290-301. 